variation in temper, or if the distribution of heat be very irregular and the changes of temperature abrupt." However, this, to me, is only partial and does not touch the root of the matter-a molecular dissymmetry.

Perhaps this comment is totally uncalled for, but as there are already so many apparently different phenomena and "effects," in physics, it is well, when we can, to ascribe all modifications of any effect, that are manifestly due to the same principle, to that effect, instead of setting it down as a nere phenomenon.

W. R. 'Turnbull.

Ithaca, N. Y.

Birds Singing on Their Nests.

IT is one of the encouraging hopes in natural science that taking anything for granted is giving way to facts. It is but a few years ago when one of our popular ornithologists said that birds were silent on their nests, else it would betray their nests. I had never seen anything in print to the contrary, up to $\mathbf{1 8 8 6}$, when I discovered the nest of a white-eyed vireo from hearing the song proceed from one direction. I cautiously followed it, to find the bird on the nest. And here I may say I saw the male and female change places on the nest about noon every fifteen or twenty minutes; the male singing all the time on the nest as heartily as when off it. In February, I892, I communicated these facts to the Ornithologist and Oölogist. It came out in "Bird Notes" in March, 1892, after which several correspondents from widely differing localities testified to hearing other species of vireos and the blackheaded grosbeak of California singing on the nest.

In the April number of the Ornithologist and Oölogist, I 892, Clyde L. Keller writes: "It seems to be a trait peculiar to that family (vireos). I have observed both cassius and the western warbling vireo singing on their nests." In the next month, May, Mr. S. R. Ingersoll writes: "Let me add both the red-eyed and warbling vireos singing on their nests, especially the latter variety" (speaking of the eastern warbling vireo). This takes in so many of the vireos that it is probable all the family have this peculiarity. One may at first wonder that it was so long undiscovered. I think the solution lies in the fact that all these birds I hear of not being silent on the nests are all birds that have their nests well concealed. I had looked many years in vain for a goldfinch's nest before I could find one, till my ears helped me. Passing by a tree several times a day, I heard the voice of a female in the tree answering the call of a passing male. After searching some time I discovered her sitting on her nest, as well concealed as a goldfinch knows how to do it, so that the risk of betraying the nest is not gieat, with such birds as we now know to sing on their nests.

Ridgewood, N. T.

$$
\text { Henry Hales. }
$$

\section{Effects of Weather on Scientific Work.}

VERY few persons recognize the sources of error that come directly from atmospheric conditions on experimenters and observers and others. In my own case I have been amazed at the faulty deductions and misconceptions which were made in damp, foggy weather, or on days in which the air was charged with electricity and thunder storms were impending. What seemed clear to me at these times appeared later to be filled with error. An actuary in a large insurance company is obliged to stop work at such times, finding that he makes so many mistakes which he is only conscious of later that his work is useless. In a large factory from ten to twenty per cent less work is brought out on damp days and days of threatening storm. The superintendent in receiving orders to be delivered at a certain time takes this factor into calculation. There is a theory among many persons in the fire insurance business that in states of depressing atmosphere greater carelessness exists and more fires follow. Engineers of railway locomotives have some curious theories of trouble, accidents and increased dangers in such periods, attributing it to the machinery. These are common illustrations and can be confirmed in the experience of all thoughtful observers. If some one would gather up reliable facts and tabulate them in this field, no doubt some laws of mental activity would be found. In an inquiry among active brain workers in my circle I find a settled conviction that many very powerful forces coming from what is popularly called the weather control the work and its success of each one. The psychology of the weather should be a most pregnant new land for study, and I would be pleased to hear from any one who may have some personal experience on this topic, for the purpose of making some future studies for the readers of Science.

Hartford, Conn.

T. D. Crothers, M.D.

\section{A Freak of Inflorescence.}

Among several hyncinths blooming in the window there is one which reverses the usual order of inflorescence. Its first spike of flowers was normal, that is, indeterminate, but the second began to bloom at the top, its lowest blossoms opening about the same time as the upper ones on the first spike. A spike on another plant began near the middle to open its flowers, and continued the process in both directions.

My observation of "late-blooming trees" has been that generally the second blossoming occurs only when the normal action of the tree has been in some way thwarted. A number of Duchesse pear trees blooming so early as frequently to get touched by frost are almost sure to bear clusters of blossoms the following August. A Siberian crab, in one of its off years, bore in July several clusters of flowers. These were larger than the ordinary flowers, and nearly as double as a Baltimore Belle rose. The summer flowers of the pear trees, on the contrary, are generally not so large, nor so many in a cluster as the spring flowers.

Lucy A. Osband.

Ypsilanti, Mich.

\section{Maya Hieroglyphs.---A Correction.}

In my first article on the "Interpretation of Maya Hieroglyphs by their Phonetic Elements" (Science, Dec. I5, I 893 ), p. $325,2 \mathrm{~d}$ col., $3 \mathrm{~d}$ line from bottom, for I 62 read I02; p. $327,2 \mathrm{~d}$ col., 5 th line, for 123 read $125 ; 43 \mathrm{~d}$ line, for ${ }^{3} 6$ read 128 , I $29 ;$ p. 328 , ist col., $32 \mathrm{~d}$ line, for mout read mouth; 4th line from bottom, for 84 read 86 ; 2 oth line from bottom, for 166 read $167 ; 2$ ist line from bottom, for 165 read 166 ; fig. 35 should have been given in the illustration, but was omitted from the drawing sent. It is composed of three squares, similar to those given in fig. I28, and has the phonetic value $\mathrm{xa} v / \mathrm{s}$, sha $\mathrm{v} / \mathrm{s}$, cha $\mathrm{v} / \mathrm{s}$.

H. T. CRESSON.

\section{The Native Calendar of Central America and Mexico.}

In Science, Feb. 2, and also in the American Anthropologist for January, Dr. Cyrus Thomas publishes some observations on the above subject, bearing upon my recent work, "'The Native Calendar of Central America and Mexico" (Philadelphia, I893). As Dr. Thomas is evidently under some misapprehensions as to my statements, I beg to place them in a somewhat clearer light.

In the Anthropologist he undertakes to correct some of my quotations from the writings of Dr. Ed. Seler; but from his own words, it is plain that Dr. Thomas is very 